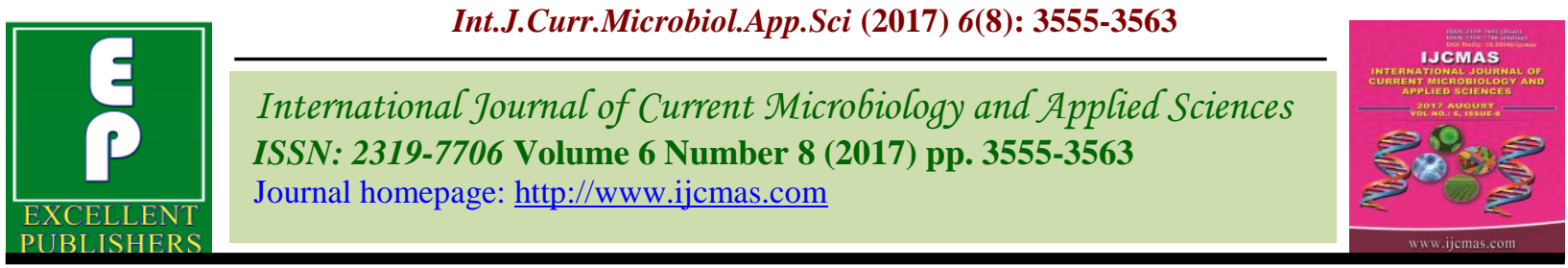

Original Research Article

https://doi.org/10.20546/ijcmas.2017.608.426

\title{
Status Problem and Prospects of Chickpea Production in Bihar: A Situation Analysis
}

\author{
Meera Kumari $^{1 *}$ and Ravi Gopal Singh ${ }^{2}$ \\ ${ }^{1}$ Bihar Agricultural University, Sabour, Bhagalpur-813210, India \\ ${ }^{2}$ International Maize and Wheat Improvement Center (CIMMYT), Apdo. \\ Postal 6-641, 06600 Mexico, D.F., Mexico \\ *Corresponding author
}

\section{A B S T R A C T}

Chickpea is one of the major pulse crops in Bihar. Its productivity $(1000 \mathrm{~kg} / \mathrm{ha})$ in the state

Keywords

Chickpea

production,

cropping pattern,

constraints, Bihar.

Article Info

Accepted:

27 June 2017

Available Online:

10 August 2017

is significantly higher than the national average of $841 \mathrm{~kg} / \mathrm{ha}$. Despite of huge potential and the comparative advantage, the production of chickpea in the state has experienced a major setback, owing to a drastic decline in the area under the crop about $60 \%$ till 2011 , to identify the problem and opportunity, the study revealed that the average productivity of improved variety of chickpea in adopted villages ranged between $950 \mathrm{~kg} \mathrm{ha}^{-1}$ for improved varieties to $850 \mathrm{~kg} \mathrm{ha}^{-1}$ for local varieties. The per capita income in the adopted village is more than that of control village which $54 \%$ of income derived from the crop enterprises only. Comparative cost and benefit analysis indicated that pulses crop are more remunerative crop for Banka district compared to Bhagalpur district (1.6) as benefit cost ratio for local varieties was higher (1.9) in Banka. But for improved verities it was estimated higher in Bhagalpur (2.01). Constraints analysis indicated that moisture stress, high pod borer incidence, shortage of labor especially during harvesting and threshing and inappropriate selection of variety in flood affected area were the key critical constrains in the achieving high yield of chickpea.

\section{Introduction}

The areas and production of chickpea have significantly improved in India during the last 10 years, it has been increased from 5.19million ha in2001-02 to9.93 million ha, in 2013-2014 while the productivity increase during the same time was from $744 \mathrm{Kg}$ ha-1in the year 2001-02 to 960.kgha-1 in (year) (Govt. of India 2014). This increase is possible due to increase in area, production and productivity in major chickpeas growing states like Maharashtra, M.P., Rajasthan, Andhra Pradesh, Karnataka and Gujarat. (IIPR-2012, fertilizer statistics 2012).
In Bihar too agriculture sector has experienced a considerable growth during the past three decades. The progress has been spectacular in 1980's when state recorded agriculture growth of 2.50 percentages which outpaced the population growth $(2.35 \%)$ during the period which could not be sustained during nineties (AICRPs, 2011). In the process of technological development in Bihar, pulse crops got major setback and its area declined from 1626thousand hectare in 1970-71 to 524.34thousand hectare in the year 2011-12. It produces 519.87 thousand $t$ of 
pulse (Govt. of Bihar 2014). This is only $4 \%$ of pulse production of the country. The percentage area under pulses to gross cropped area has also declined with an increase in gross irrigated area (Chopra, 1982). Among pulse crop grown in Bihar lentil is the only pulse crop whose cropped area increased by 20,000 hectares. Its production is still greater to all India average $(991 \mathrm{~kg} / \mathrm{ha})$. Particular reference to chickpea in Bihar, the area of chickpea has declined from 2.45 lakh in 197576 to 0.56 lakh hectare in2010-11although productivity has increased from $550 \mathrm{~kg} / \mathrm{ha}$ to $1000 \mathrm{~kg} / \mathrm{ha}$ during the same period, even after 2003, the chickpea area has been in declining trend due to growing popularity and public policy emphasis on Rice-Wheat system (Anonymous, 2012). It has been noticed that as irrigation facilities developed, chickpea gradually gets marginalized in Bihar and other parts of Indo-Genetic Plains (Ranjan, 1996). In addition to this, there is a huge variability in area and production of chickpea during 2000-2009, however the productivity during the same period is more stable which indicates that there is a scope to increase production potential of chickpea in the state if adequate policy measures are taken (Kumari et al., 2015). In this regard it is pertinent to take into account the 2.6 million haof rice fallow land in the state to which the chickpea cultivation could be potentially expanded (F.A.O., 2009; Singh, 2012) To identify the problem and opportunity, this paper has been planed with main aimed at increasing the area and production of chickpea through intervention of improved varieties along with management practices in target districts of Bihar.

\section{Materials and Methods}

The study was mainly based on collection of primary data the target districts for conducting baseline survey on "chickpea cultivation in Bihar" was two districts of
Bihar: Banka and Bhagalpur in 2011-12 under collaborative project of TL-2. In each district a cluster of 3 villages from two different blocks were selected as adopted village and 3 villages from surrounding areas with comparable agro ecological and market condition were chosen to serve as control villages. In total, a cluster of 3 villages from adopted and 3 villages from control i.e. 6 villages in each district were identified for the same. Stratified Random Sampling technique based on probability proportion to size method to farm size was used to conduct the interview. From each of the adopted villages a sample of 30 farmers were interviewed and from each of the control villages a sample of 15 farmers were interviewed. Thus, a total of 135 from each district totalling to 270 farmers were interviewed.

\section{Analytical technique}

For assessing the trends in area, production and productivity of chickpea in the states and the study districts of Bhagalpur and Banka, the exponential function of ${ }^{\mathrm{YT}}=a b^{t} u^{t}$ was employed. Where, ${ }^{\text {YT }}=$

area/production/productivity in the year's' $\mathrm{a}=$ intercept indicating $\mathrm{Y}$ in the base period $(\mathrm{t}=$ $0)$,

$\mathrm{B}=$ Regression coefficient

${ }^{\mathrm{t}}=$ Time period in years

$\mathrm{U}^{\mathrm{t}}=$ Disturbance term for the year's'.

\section{Garrett's ranking techniques}

It was used for constraints analysis, in this analysis, rank 1 means most important problem and rank 10 means least important problem. In the next stage rank assigned to each reason by each individual was converted into per cent position using the following formula: Per cent position $=100(\mathrm{Rij}-0.5) /$ NJ Where, Rij stands for rank given for the $I^{\text {th }}$ factor $(i=1,2 \ldots .5)$ by the $j$ th individual $(j=1$, 
$2 \ldots \ldots, \mathrm{n}) \mathrm{Nj}$ stands for number of factors ranked by $\mathrm{j}^{\text {th }}$ individual. Once the per cent positions were found, scores were determined for each per cent position by referring Garrett's table. Then, the scores for each problem were summed over the number of respondents who ranked that factor. In this way, total scores were arrived at for each of the factors and mean scores were calculated by dividing the total score by the number of respondents who gave ranks. Final overall ranking of the factors was carried out by assigning rank $1,2,3 \ldots$ etc., in the descending order of the mean scores.

\section{Major findings}

Status and importance of chickpea in sample districts of Bihar. Relative importance of pulses in the districts as a wholewas 20 percent of gross cropped area. Among pulses chickpea accounts 60 percent of area to total pulses area in the districts. Since the past few decades, the area under chickpea has been declined but productivity is more stable. In Bhagalpur, the average area under chickpea in triennium ending 2000was5042 hectare producing 4416 tons with productivity of 872 $\mathrm{kg}$ per hectare. It shown an increasing trend of area and production during the triennium ending 2009 but productivity during the same has been declined to $744 \mathrm{~kg} / \mathrm{ha}$. Chickpea is also one of the major pulse crops in Banka district with an area of 3873 ha during 2000 after that it has declined to 2477ha till 2009 triennium ending however average production has been stagnated over the same period. But productivity level has shown an increasing trend as rises from716 kg/ha to $1057 \mathrm{~kg} / \mathrm{ha}$. This requires the suitable policy to develop the technology of processing, storage and sustainable production for the livelihood security of people in Bihar.

As chickpea is cheapest source of protein and has multipurpose use, especially in Bhagalpur district people used it as Bassoon, sattu and whole chana dal and also as substitute of vegetable during the off season when the price of vegetable in market is very high, people could not afford to buy at that rate using chickpea as vegetable purpose.

It may be noted that the relative importance of chickpea crop to total cropped area (Kharif, Rabi and summer) was accounted nearly about 20 to 36 percent in control and adopted Village respectively. Size group analysis revealed that the pulse crops were given more importance by the large farmers followed by small and marginal farmers, due to the fact that pulse crop being less capital intensive may be cultivated extensively to cover all the land under cultivation particularly by the large farmers. From the observation of cropping pattern of sample districts it may be inferred that district Bhagalpur is dominated by crop of chickpea in Rabi followed by kharif crop across each size group of farms. It clearly indicates that pulse crops were not given equal importance as given to the wheat, maize and paddy by the farmer of selected districts (Table 1).

\section{Productivity of chickpea}

Varieties -wise analysis indicated that data pertaining to average productivity of improved varieties did better in Banka $(1042.34 \mathrm{~kg} / \mathrm{ha})$. Among all varitiesJG-14 proved superior over kak-2 $(832.74 \mathrm{~kg} / \mathrm{ha})$ inparticular location but it was observed that they were reaping only half of potential yield they obtain due to postharvest losses, germination problems, high disease infestation etc. Despite of these problems farmers have expressed their preference to grow the improved varieties in next season (Table 2).

Data pertaining to productivity level of 'Deshla plain' was concerned it gives 
comparatively higher yield in adopted village of Banka (776.09 kg/ha) followed by adopted villages of Bhagalpur $(668.66 \mathrm{~kg} / \mathrm{ha})$. Thus it is clear from table 6 that the average yield of chickpea in Banka is comparatively higher than that of Bhagalpur. Among improved variety given to the farmer JG-14(1000kg/ha) gives better yield in bank followed by RADHA $(1010.45 \mathrm{~kg} / \mathrm{ha})$ and KAK-2 which was also reported by the farmer as most preferred variety among improved cultivar (Table 3). On the basis of above observation i.e. comparative yield analysis of both district it may concluded that, farmers of both districts were still relying on traditional varieties due to risk associated with improved varieties, high level of occurrence of disease and pest, Germination problems of KAK2 in few villages like Raipur. Postharvest losses in KAK2 were also higher due to rat attack on farmer field. For Better impact large number of farmer should have been identified for distribution of seed, early sown variety should be given to the farmers of flood affected area, and late sown variety should be promoted in rice-wheat dominated areas of all villages selected under study.

\section{Economic analysis of chickpea cultivation}

Economic analysis of growing different crops is very important to understand which crop is most remunerative in terms of getting higher return on investment. The cost of cultivation, input output ratio associated with growing chickpea has been presented below.

It could be observed from the table 4 that proportion of expenditure on human labor was found highest on harvesting and threshing (Rs5532.33) followed by material input like seed cost (Rs 3286) in adopted and control village (4554.01 and 2645) respectively out of total cost Rs 15392 /ha and 14352 spent on cultivation of chickpea under study. However the cost of cultivation of improved varieties was varies between Rs18200-19280/ha which was comparatively higher than local variety. It was mainly due to fact that while using local variety farmer were using own seed and due to higher prices of improved seed and proper package of practices used by the famer while cultivating improved varieties. The estimated net return wasRs13438 to14368 /ha in sample village for local varieties and Rs17480- 19520 for improved varieties under studies. It clearly indicated the comparative advantage of chick pea than other competing crop like wheat (compiled other crop also).Comparative cost and benefit analysis indicated that pulses crop are more remunerative crop for Banka than Bhagalpur (1.6) as benefit cost ratio for local verities were higher (1.9) in Banka. But for improved verities it was estimated higher in Bhagalpur (2.01).It means improved variety given to farmer were found more suitable in Bhagalpur districts. Results supported by the findings of Meena et al., in 2014.

It may be observed that total household income on an average was worked out to be Rs. 250782 for adopted villages of Bhagalpur which was found to be highest followed by adopted village of Banka district (Rs.169839).

Among control villages it was comparatively higher for Banka district than that of Bhagalpur and was estimated to be Rs.130629 and Rs.113407 respectively. Besides, contribution of farm income in adopted villages was found comparatively higher than control villages of both the districts (Table 5).

Regular salaried Job figured to be the major source of income in both the districts i.e. contribution of non-farm income was estimated about 82061 for adopted villages of Bhagalpur and Rs.82167/Year for adopted villages of Banka. Earning from business figured out to be the third most important source of income and accounted for about 
Rs.2277 out of Rs.130629followed (Rs.12222) and (Rs.9967) respectively by adopted and control villages of Bhagalpur. It was further revealed that contribution of income to the total income from crop was Rs70983.5in adopted village which was accounted next to salaried job placed second and in control village it was estimated only Rs26905.5, despite of the fact that majority of part of population of selected districts i.e. 53 $\%$ of total population mainly depend upon agriculture followed by business and services.

Table.1 Area, production and productivity in major districts (1997 to 2012) and instability measures (Area in '000 ha and Productivity in $\mathrm{kg} / \mathrm{ha}$ ))

(Area in '000 ha and Productivity in $\mathrm{kg} / \mathrm{ha}$ )

\begin{tabular}{|c|c|c|c|c|c|c|}
\hline \multirow{2}{*}{} & \multicolumn{3}{|c|}{ BHAGALPUR } & \multicolumn{3}{c|}{ BANKA } \\
\cline { 2 - 7 } & Area & Production & Yield & Area & Production & Yield \\
\hline $\mathbf{2 0 0 0}$ & 5042 & 4416 & 872 & 3873 & 2703 & 716 \\
\hline $\mathbf{2 0 0 3}$ & 3619 & 3012 & 823 & 3008 & 1836 & 745 \\
\hline $\mathbf{2 0 0 6}$ & 3144 & 2126 & 663 & 3561 & 2680 & 745 \\
\hline $\mathbf{2 0 0 9}$ & 6162 & 4619 & 744 & 2477 & 2783 & 1057 \\
\hline $\mathbf{1 9 9 7 - 2 0 0 3}$ & 27.46 & 30.29 & 13.74 & 17.10 & 29.04 & 20.43 \\
\hline $\mathbf{2 0 0 3 - 1 2}$ & 83.63 & 83.63 & 23.09 & 40.27 & 54.33 & 31.94 \\
\hline $\mathbf{1 9 9 7 - 2 0 1 2}$ & 57.79 & 58.35 & 19.05 & 30.51 & 43.38 & 30.02 \\
\hline \multicolumn{7}{|c|}{ De-trended data(cv) } \\
\hline $\mathbf{1 9 9 7 - 2 0 0 3}$ & 0.04 & 0.04 & 0.31 & 0.07 & 0.09 & 0.34 \\
\hline $\mathbf{2 0 0 3 - 1 2}$ & 0.24 & 0.10 & 0.43 & 0.07 & 0.08 & 0.26 \\
\hline $\mathbf{1 9 9 7 - 2 0 1 2}$ & 0.10 & 0.01 & 0.10 & 0.01 & 0.02 & 0.13 \\
\hline
\end{tabular}

Source: (Directorate of Economics\& Statistics, Govt. of Bihar, estimated by authors)

Table.2 Relative importance of chickpea crop in cropped area of Bihar sample, 2011-12

\begin{tabular}{|l|c|c|c|c|c|c|}
\hline \multicolumn{2}{|c|}{ Cropped area } & \multicolumn{2}{l|}{ BHAGALPUR } & \multicolumn{2}{l|}{ BANKA } & \multicolumn{2}{l|}{ Pooled Sample } \\
\cline { 2 - 7 } & A & C & A & C & A & C \\
\hline $\begin{array}{l}\text { Rainy season cropped area } \\
\text { (ha) }\end{array}$ & 55.66 & 16.39 & 73.53 & 32.18 & 129.19 & 48.58 \\
\hline $\begin{array}{l}\text { Post rainy season cropped } \\
\text { area (ha) }\end{array}$ & 321.40 & 20.14 & 82.94 & 36.84 & 404.35 & 56.98 \\
\hline $\begin{array}{l}\text { Area under post- rainy season } \\
\text { chickpea area post rainy area } \\
\text { (ha) }\end{array}$ & 60.17 & 16.49 & 45.90 & 21.96 & 106.07 & 38.46 \\
\hline $\begin{array}{l}\text { Proportion of chickpea area to } \\
\text { total cropped area (\%) }\end{array}$ & 16 & 45 & 29 & 32 & 20 & 36 \\
\hline
\end{tabular}

(Source: compiled by the Authors) 
Table.3 Productivity of chickpea by varieties in Bihar sample, 2011-12 (kgspe ha)

\begin{tabular}{|l|c|c|c|c|c|c|}
\hline & \multicolumn{2}{|l|}{ BHAGALPUR } & \multicolumn{2}{c|}{ BANKA } & \multicolumn{2}{c|}{ Pooled Sample } \\
\cline { 2 - 7 } & Adopted & Control & Adopted & Control & Adopted & $\begin{array}{c}\text { Contr } \\
\text { ol }\end{array}$ \\
\hline $\begin{array}{l}\text { DESHLA } \\
\text { ROON }\end{array}$ & 732.77 & 741.00 & 946.83 & 900.35 & 848.03 & $\begin{array}{c}890.7 \\
0\end{array}$ \\
\hline & & & & & & 627.1 \\
DESLA PLAIN & 668.66 & 626.32 & 776.09 & 638.08 & 702.53 & 1 \\
\hline JG-14 & 790.40 & 0 & 1042.34 & 0 & 1000.35 & 0 \\
\hline KAK-2 & 988.00 & 0 & 806.87 & 0 & 832.74 & 0 \\
\hline & 864.50 & 494.00 & 0 & 671.84 & 1010.45 & $\begin{array}{c}630.8 \\
0\end{array}$ \\
\hline RADHA & 839.80 & 0 & 0 & 370.50 & 790.40 & $\begin{array}{c}370.5 \\
0\end{array}$ \\
\hline SUBHARA & 699.83 & 0 & 0 & 0 & 699.83 & 0 \\
\hline VAIBHAV & & & & & & \\
\hline
\end{tabular}

(Source: compiled by the Authors)

Table.4 Gross returns and cost incurred from different verities grown by

Sample farmers in Bihar 2011-12 (Rs.'000/ha)

\begin{tabular}{|c|c|c|c|c|}
\hline & \multicolumn{2}{|c|}{ BHAGALPUR (Rs per ha) } & \multicolumn{2}{|c|}{ BANKA (Rs per ha) } \\
\hline & Adopted & Control & Adopted & Control \\
\hline \multicolumn{5}{|c|}{ Rain fed /Local DESHLA PLAIN (LOCAL) DESHLA RUN(LOCAL) } \\
\hline Yield (kg/ha) & 708 & 616 & 794 & 839 \\
\hline COC(Rs/ha) & 15392 & 11942 & 14352 & 14997 \\
\hline Gross returns(Rs/ha) & 24780 & 21560 & 27790 & 29365 \\
\hline Net returns (Rs/ha) & 9388 & 9618 & 13438 & 14368 \\
\hline BCR & 1.6 & 1.8 & 1.9 & 1.95 \\
\hline \multicolumn{5}{|c|}{ Irrigated /Improved IMPROVED KAK-2(IMPROVED) } \\
\hline Yield (kg/ha) & 970 & 0 & 892 & 0 \\
\hline COC (Rs/ha) & 19280 & 0 & 18200 & 0 \\
\hline Gross returns (Rs/ha) & 38800 & 0 & 35680 & 0 \\
\hline Net returns (Rs/ha) & 19520 & 0 & 17480 & 0 \\
\hline BCR & 2.01 & 0 & 1.96 & 0 \\
\hline
\end{tabular}

(Source: compiled by the Authors) 
Table.5 Net household income of sample farmers, in 2011-12 (Rs/Year)

\begin{tabular}{|l|c|c|c|c|c|c|}
\hline \multirow{2}{*}{ Source of income } & \multicolumn{2}{l|}{ BHAGALPUR } & \multicolumn{2}{l|}{ BANKA } & \multicolumn{2}{l|}{ Pooled } \\
\cline { 2 - 7 } & Adopted & Control & Adopted & Control & Adopted & Control \\
\hline Income from crops & 92717 & 27544 & 49250 & 26267 & 70983.5 & 26905.5 \\
\hline Farm work (labor earnings) & 28367 & 11156 & 15744 & 12311 & 22055.5 & 11733.5 \\
\hline $\begin{array}{l}\text { Non-farm work (labor } \\
\text { earnings) }\end{array}$ & 11222 & 7089 & 7000 & 7667 & 9111 & 7378 \\
\hline Regular Farm Servant (RFS) & 622 & 1556 & 0 & 444 & 311 & 1000 \\
\hline $\begin{array}{l}\text { Livestock (milk and milk } \\
\text { products selling) }\end{array}$ & 3611 & 2844 & 611 & 21111 & 2111 & 2477.5 \\
\hline $\begin{array}{l}\text { Income from hiring out } \\
\text { bullocks }\end{array}$ & 0 & 222 & 0 & 0 & 0 & 111 \\
\hline $\begin{array}{l}\text { Income from selling sheep, } \\
\text { goat, chicken, meat, eggs etc. }\end{array}$ & 1172 & 729 & 378 & 4356 & 775 & 2542.5 \\
\hline $\begin{array}{l}\text { Selling of water for } \\
\text { agriculture purpose }\end{array}$ & 0 & 0 & 0 & 67 & 0 & 33.5 \\
\hline $\begin{array}{l}\text { Rental income (tractor, auto, } \\
\text { sprayer, \& truck etc.) }\end{array}$ & 2444 & 133 & 1600 & 0 & 2022 & 66.5 \\
\hline Business (specify) & 12222 & 9667 & 5667 & 23295 & 8944.5 & 16481 \\
\hline $\begin{array}{l}\text { Regular salaried jobs } \\
\text { (Govt./private) }\end{array}$ & 82061 & 39956 & 82167 & 35111 & 82114 & 37533.5 \\
\hline Out migration & 6111 & 5000 & 0 & 0 & 3055.5 & 2500 \\
\hline Pension from employer & 10233 & 7511 & 7422 & 0 & 8827.5 & 3755.5 \\
\hline Grand Total & 2,50782 & 1,13407 & 1,69839 & 1,30629 & $2,10310.5$ & 1,12518 \\
\hline
\end{tabular}

(Source: compiled by the Authors)

Table.6 Major constraints among cultivars (Wt. Scale)

\begin{tabular}{|c|c|c|c|c|}
\hline \multirow[t]{2}{*}{ CONSTRAINTS } & \multicolumn{2}{|c|}{ BHAGALPUR } & \multicolumn{2}{|c|}{ BANKA } \\
\hline & $\operatorname{Local}(d . p)$ & Local(d.r) & Local & Improved \\
\hline Low yield & $1^{\mathrm{st}}$ & & $1^{\mathrm{st}}$ & $2^{\text {nd }}$ \\
\hline High pod borer incidence & $2^{\text {nd }}$ & $1^{\mathrm{st}}$ & $2^{\text {nd }}$ & $1^{\mathrm{st}}$ \\
\hline High disease incidence & & $3^{\text {rd }}$ & $3^{\text {rd }}$ & $3^{\text {rd }}$ \\
\hline Long duration & & & & $4^{\text {th }}$ \\
\hline Small grain size & $5^{\text {th }}$ & & $4^{\text {th }}$ & \\
\hline Not attractive colour & $4^{\text {th }}$ & $2^{\text {nd }}$ & & \\
\hline Poor taste & & $5^{\text {th }}$ & & \\
\hline Low recovery of dal (\%) & & & & \\
\hline Low market price & 3 th & & & \\
\hline Not fit into cropping system & & $4^{\text {th }}$ & $5^{\text {th }}$ & \\
\hline Poor fodder quality & & & & \\
\hline Susceptible to storage pest & & & & $5^{\text {th }}$ \\
\hline
\end{tabular}

(Source: compiled by the Authors) 


\section{Problem and prospects of chickpea production}

Many problems or constraints were observed on sample farms which were pooled into following categories namely, low yield, pest and disease, long duration, small grain size, lack of technical knowledge, low market price or pulse production being not profitable etc. The constraints involved in chickpea production were identified and ranked according to weighted mean scale or in form of proportion of farmers who given priority for that observed occurrence of the problem on their farm and the results have been presented table 6 .

The findings clearly indicated that major constraints among cultivar in Bhagalpur for local variety was low yield followed by high pod borer incidence, low market price, having no attractive color and small grain size was ranked $1^{\text {st }}, 2^{\text {nd }} 3^{\text {rd }}, 4^{\text {th }}$ and $5^{\text {th }}$ respectively. As far as for improved varieties it was, high pod borer incidence followed by having not attractive color, High disease incidence, not fitting into cropping system and poor taste were given the $1^{\text {st }} 2^{\text {nd }}, 3^{\text {rd }}, 4^{\text {th }}$ and $5^{\text {th }}$ ranked respectively.

In Banka district, the major constrains in order of importance were low yield, high pod borer incidence, high disease incidence, small grain size and low recovery of dhal percentage as $1^{\text {st }}, 2^{\text {nd }}, 3^{\text {rd }}$, and $5^{\text {th }}$ rank respectively for local variety and high pod borer incidence followed by low yield, high disease incidence, long duration\& not fitting into cropping system as $1^{\text {st }}, 2^{\text {nd }}, 3^{\text {rd }}, 4^{\text {th }}$, and $5^{\text {th }}$ respectively for improved variety.. Thus it may be concluded that major constraints among cultivar was the pest and disease for improved variety and Low yield was the main problem for local varieties of chickpea production in study districts of Bihar. Pulses in Bihar also go through a large supply chain which drives up the prices of consumers. This is generally due to large number of intermediaries who take their cut of the value of the pulses. It is estimated that each middle men in the supply chain takes at least 1 to $2 \%$ commissions on their sales. There is a good scope for pulses industry also that's why special attention in these areas needs to explore the technology for optimisation of pulse production in study distracts as well as state as a whole.

In conclusion, Decline in area of chickpea was mainly due to insecure harvest of crop in isolated pockets due to social factor. Heavy losses in production of chickpea due to insect's infestation mainly pod borer, socioeconomic constraints, problems of market, lack of improved varieties etc. Among variety targetedJG-14, KAK2 and Subhra were found most acceptable and suitable variety in the farmer's field of both the districts in Bihar. However major problem associated with these are germination, non-suitability into cropping pattern, post-harvest losses due to rat attack etc. However profitability of chickpea is comparatively more than others traditionally grown varieties. Regarding local variety one of the major setbacks is that it has not been replaced by the farmer from 20 to 25 years. Major constraints for chickpea production in Bihar are that, the suitable variety is not available in the market; erratic rainfall causes moisture stress, disease and insect infestation etc. To increase area and production of chickpea we need region specific approaches which should be adopted in the overall framework of system approach. There is a good scope for pulses industry also that's why special attention in these areas needs to explore the technology for optimisation of pulse production. Because, for diversification chickpea is one of the reliable option with new technology interventions (improved seed, package and practise) to regain some area in the state as whole and districts in particular. The policy recommendations which have 
emerged out from the paper and merit the attention of the policy makers are that, farmer should replace their own seed with improved varieties for getting higher productivity. Secondly for getting higher prices there is a need to improve market information system and for diversification chickpea is one of the reliable options with new technology interventions (improved seed, package and practice) to regain some area in the state as whole and districts in particular, the coordination of research extension and farmers to encourage farmer's participatory research would be need of the day. For getting better impact tal and diara land along with large number of beneficiaries should be included while targeting the area.

\section{References}

AICRPs (2011) Annual Report on Gram, Arhar, Moong, Urad, undertaken by Indian Institute of Pulse Research, Kanpur.

Anonymous (2012).Directorate of Economics and Statistics, Ministry of Agriculture and Cooperation Government of India.

Chopra, K. (1982) Pulse production in India- A state wise Analysis, Indian Journal of Agril. Economics37 (3): pp 371 - 380 .

Directorate of Economics and Statistics (2011) Government of Bihar. Ministry of Agriculture and Cooperation Government of India.

Dubey, A. K., Srivastava, J. P. and Sharma, V. K. (2008). Attitude of respondents towards KVK training programmes. Indian Research Journal Extension Education. 8(2/3):78-80

Government of India 2000 Expert Committee Report on Pulses, Technology Mission on Oilseeds and Pulses, Department of Agricultural and Cooperation, Ministry of Agriculture, New Delhi.
Government of Bihar (2008), Bihar Economic Survey-2008-09, Ministry of Finance, Patna, March, pp.23.

Government of Bihar (2008), Bihar through Figure, Department of Statistics and Evaluation, Patna

Government of India (2008), Bihar's Agricultural Development: Opportunities and Challenges", A Report of the Special Task Force on Bihar, New Delhi, April, p.16.

Meena, L. K., Bairwa, S. L., Lakra, K., and Sirohiya, L. (2014). Analysis of the profile on participating and non-participating farmers in chickpea production technology. Agricultural Update9 (1): 31-36.

Ranjan, K. P and Singh, R.K.P. (1998) Cropping Pattern in Backward Agriculture - A Case of North Bihar. Agricultural Situation in India. pp. $69-72$.

Ranjan, K. P. (1996) Pulse production in North Bihar during Post-green Revolution Period. The Bihar Journal of Agricultural Marketing. 4 (4): pp $407-416$.

Salam, M. A., Anwer, M. E. and Alam, M. S. (2013) an analysis Agriculture and the economy of Bihar: International Journal of Scientific and Research. 3(11) pp. 1-19.

Kumari, M., Meena, L. K. and Bairwa, S.L. (2015) Socio Economic Assessment of Chickpea Growers in Bihar, India. International Journal of Agricultural Science and Research (IJASR) 5 (4): 21-28.

Kumari, M, Bhattarai, M., Kumar, R.and Jyotsna2014.Targeting chickpea cultivation in Bihar, $8^{\text {th }}$ Asian Society of Agril. Economist. Conference issue.

Singh, R.G., Mishra, S.K., Singh, P.K., Jat, R.K., Dey, S., Shahi, V.B., Lahri, A., Bishwas, B., Sarkar, S., Bhattacharyya, P., Kumar, S., and Gupta, R.K. 2012.Opportunities for managing rice fallow systems. Indian farming, 62 (6):31$34,40$.

\section{How to cite this article:}

Meera Kumari and Ravi Gopal Singh. 2017. Status Problem and Prospects of Chickpea Production in Bihar: A Situation Analysis. Int.J.Curr.Microbiol.App.Sci. 6(8): 3555-3563. doi: https://doi.org/10.20546/ijcmas.2017.608.426 